\title{
2018 Benefits Study of Emergency IEA Oil Stocks: Final CRADA Report
}

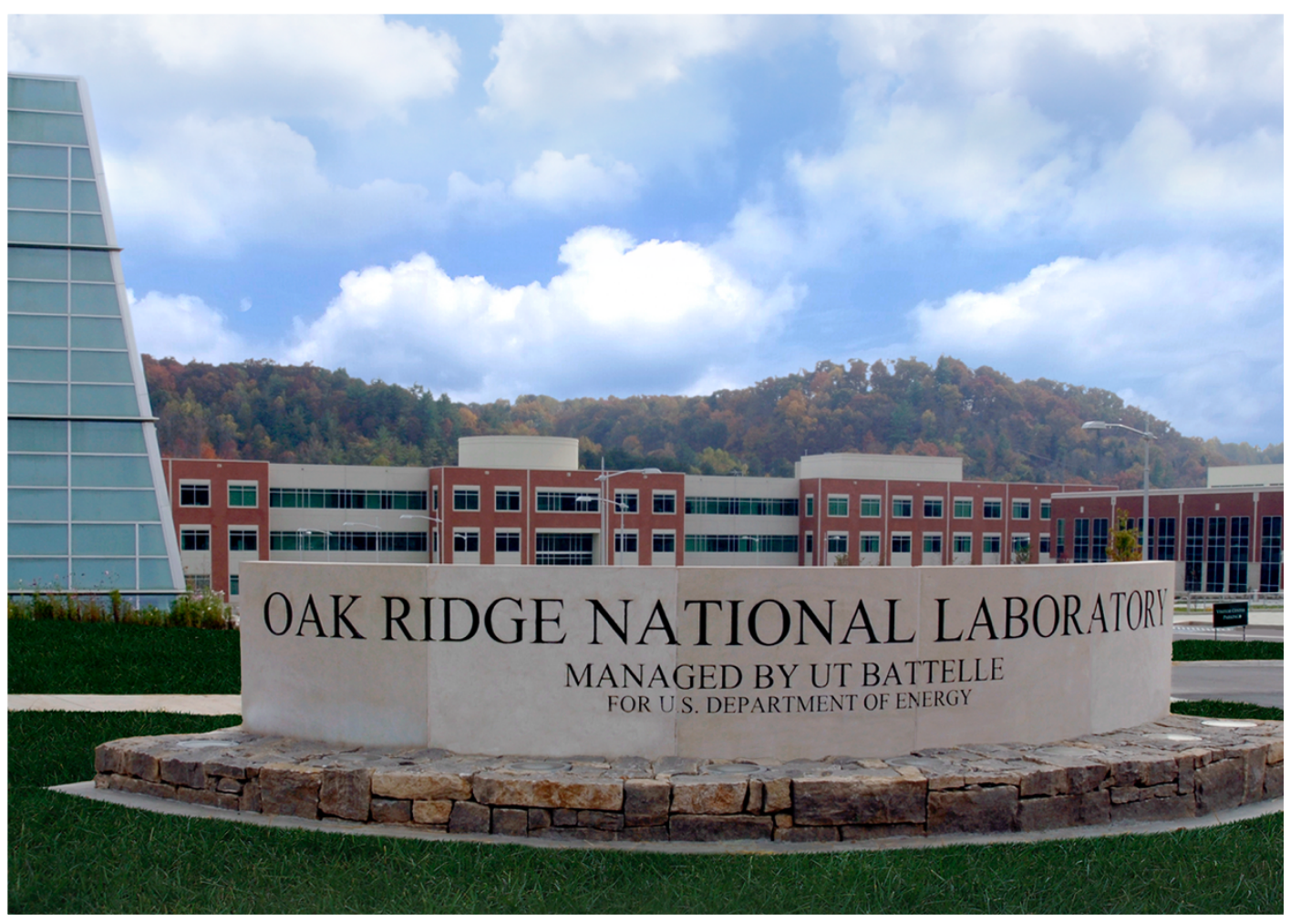

CRADA Final Report CRADA/NFE-18-07043

Approved For Public Release. Distribution is unlimited.
Paul N. Leiby Gbadebo Oladosu Rocio Uria Martinez Megan Johnson ORNL

David Bowman ECONOTECH

March 2019 


\section{DOCUMENT AVAILABILITY}

Reports produced after January 1, 1996, are generally available free via US Department of Energy (DOE) SciTech Connect.

Website http://www.osti.gov/scitech/

Reports produced before January 1, 1996, may be purchased by members of the public from the following source:

National Technical Information Service

5285 Port Royal Road

Springfield, VA 22161

Telephone 703-605-6000 (1-800-553-6847)

TDD 703-487-4639

Fax 703-605-6900

E-mail info@ntis.gov

Website http://www.ntis.gov/help/ordermethods.aspx

Reports are available to DOE employees, DOE contractors, Energy Technology Data Exchange representatives, and International Nuclear Information System representatives from the following source:

Office of Scientific and Technical Information

PO Box 62

Oak Ridge, TN 37831

Telephone 865-576-8401

Fax 865-576-5728

E-mail reports@osti.gov

Website http://www.osti.gov/contact.html

This report was prepared as an account of work sponsored by an agency of the United States Government. Neither the United States Government nor any agency thereof, nor any of their employees, makes any warranty, express or implied, or assumes any legal liability or responsibility for the accuracy, completeness, or usefulness of any information, apparatus, product, or process disclosed, or represents that its use would not infringe privately owned rights. Reference herein to any specific commercial product, process, or service by trade name, trademark, manufacturer, or otherwise, does not necessarily constitute or imply its endorsement, recommendation, or favoring by the United States Government or any agency thereof. The views and opinions of authors expressed herein do not necessarily state or reflect those of the United States Government or any agency thereof. 
Environmental Sciences Division

Final CRADA Report:

2018 Benefits Study of Emergency IEA Oil Stocks

Authors:

Paul N. Leiby

Gbadebo Oladosu

Rocio Uria Martinez

Megan Johnson

Oak Ridge National Laboratory

David Bowman

ECONOTECH

\author{
March 2019 \\ Prepared by \\ OAK RIDGE NATIONAL LABORATORY \\ Oak Ridge, Tennessee 37831-6283 \\ managed by \\ UT-BATTELLE, LLC \\ for the \\ US DEPARTMENT OF ENERGY \\ under contract DE-AC05-00OR22725
}

Approved For Public Release 


\section{CONTENTS}

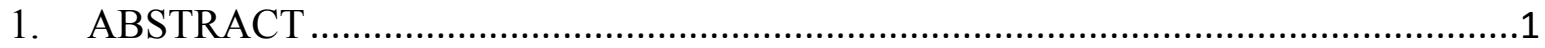

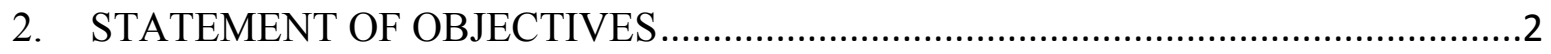

3. BENEFITS TO THE FUNDING DOE OFFICE'S MISSION …................................

4. TECHNICAL DISCUSSION OF WORK PERFORMED BY ALL PARTIES ..............3

4.1 OVERVIEW WORK PERFORMED BY ALL PARTIES ...........................................

4.1.1 OAK RIDGE NATIONAL LABORATORY …........................................

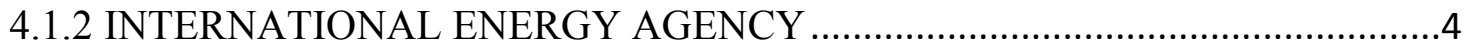

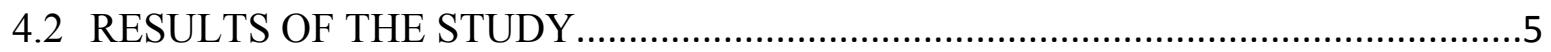

4.2.1 EXPECTED CUMULATIVE ECONOMIC BENEFITS OVER 30 YEARS .......5

4.2.2 COMPARISON TO 2012 STUDY AND SENSITIVITY ANALYSIS ...............6

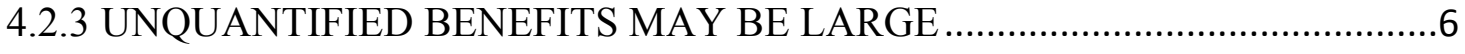

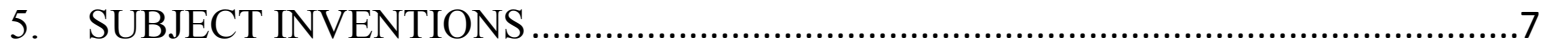

6. COMMERCIALIZATION POSSIBILITIES .............................................................

7. PLANS FOR FUTURE COLLABORATION …..................................................

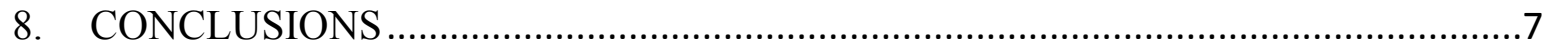

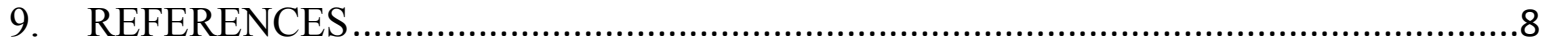




\section{ABSTRACT}

This CRADA work was performed with the International Energy Agency (IEA) by Oak Ridge National Laboratory (ORNL) to support ongoing IEA, and U.S. DOE, discussions on future oil market challenges by IEA member countries. ORNL completed an update of a 2012 study for the IEA that accounts for changes in oil market and global economic conditions since 2013. The ORNL study evaluates the collective benefits of IEA emergency oil stocks, counting benefits to all countries, not just IEA, that are net oil importers. The IEA provided oil market data and projections, provided recommendations on parameter values and key case assumptions, in coordination with IEA member countries and coordinated the ORNL study with a parallel study on stockholding costs by an IEA subcontractor. IEA also combined the results of the ORNL benefits study and the IEA-funded cost study in a summary report by IEA, Insights Series 2018 Costs and Benefits of Emergency Stockholding.

In the ORNL economic benefits study (hereafter, "the study"), economic benefits from stockholding are calculated as the expected reduction in the economic cost of oil market disruptions when stocks are used, compared to a situation where no stocks are made available. The expected economic benefits to oil importing nations from IEA emergency stocks include avoided GDP losses and net oil import costs due to moderated price increases during global oil supply disruptions. The study also provides an overview of "hard to quantify" benefits, such as foreign policy and national security benefits as well as benefits during domestic supply shocks or disruptions, but it does not formally estimate their value. The benefits analysis was performed using the ORNL BenEStock model for simulating the economic impacts of oil supply disruptions. The main findings of the study are as follows:

- Current IEA stocks offer significant protection against many potential oil supply disruptions: The current emergency stocks held by IEA countries, when used in a coordinated manner, are capable of significantly reducing the expected costs of many potential future shocks. During large or long disruptions, which cannot be fully offset by emergency stocks, stock drawdowns still provide significant partial price protection and reduce costs to oil importing regions, but significant unmitigated disruptions remain in those cases.

- Collective expected benefits of IEA emergency stocks to net oil importers in the Base case are on the order of \$61 per barrel per year: IEA stocks provide a collective total expected benefit of $\$ 61.27$ per barrel per year over the 30-year planning horizon to IEA member countries and non-IEA oil importing countries. This is the mean or average benefit from the "insurance" provided by stocks, although, like any insurance policy the actual benefits would depend on the particular oil market future ultimately realized. The $90 \%$ interval for benefits under base case conditions reflects uncertainty about oil market outcomes, and ranges from $\$ 10.96$ to $\$ 119.47 / \mathrm{bbl} /$ year.

- Two roughly-equal benefit components: Emergency oil stocks, by reducing the price shock after a supply loss, help reduce GDP losses and oil import costs. For a given country, the relative magnitudes of these two components depend on that country's level of imports and macroeconomic sensitivity to shocks. The total collective benefits to world oil importing nations from the two cost components are roughly comparable in size: \$34.61 and $\$ 26.10 / \mathrm{bbl} /$ year for avoided GDP losses and import costs respectively. Changes in net oil revenue sales and purchases make up the remainder of benefits. 
- Additional Benefits: Beyond the economic benefits from the collective use of oil stocks quantified in this study, individual countries can gain additional value from holding stocks by using them unilaterally to address local or domestic petroleum disruptions that may be too small or localized to trigger a collective IEA stock drawdown. Oil stocks can enhance a country's diplomatic flexibility and can improve national security by diminishing the need for military forces to help protect oil supply and transit. The study did not seek to quantify these other potential benefits, which is difficult due to their country-specificity, their qualitative rather than quantitative nature, and other considerations.

\section{STATEMENT OF OBJECTIVES}

The IEA is an autonomous organization which works to ensure reliable, affordable and clean energy for its 29 member-countries and beyond. Founded in response to the 1973/4 oil crisis, the IEA's initial role was to help countries co-ordinate a collective response to major disruptions in oil supply through the release of emergency oil stocks to the markets. Oil markets have experienced many supply disruptions since the IEA started coordinating oil stockholdings among its members in the early 1970s. On three occasions since 1990, coordinated, multilateral stock releases occurred and their contribution to help the market adjust was evident. Although U.S. oil production has increased since 2012 and led to significant changes in the global oil market, expectations are that global reliance on oil supply from potentially unstable sources, including OPEC, will remain significant. Both the U.S. Energy Information Administration (EIA) and OPEC expect OPEC petroleum production to remain flat until 2025 before growing to account for almost $50 \%$ of world supply. In this context, IEA member countries are engaged in planning discussions to prepare for future risks to the oil market. ORNL has developed significant analytical capabilities to inform those discussions based on more than two decades of sustained study of oil disruptions and the benefits of emergency energy stocks. ORNL's relevant experience includes a prior study of the benefits of IEA emergency stocks ("Benefits of Emergency Stocks: A Study of IEA Stocks and Benefits," Final Draft, October 3, 2012). That study quantified the economic benefits to major world regions derived from the holding of emergency oil stocks.

The goal of the current study is to update the 2012 study and quantify the future (2018-2047) economic benefits derived from holding emergency oil stocks, accounting for recent global oil market and economic developments. These benefits depend on a variety of parameters, including projected future oil market supplies and demands, the probability and the size of oil supply disruptions, the effect of such disruptions on the oil price, the size and capability of available stocks, and the impact of a subsequent oil price rise on the economy. The updated study applies the same methodology as the 2012 study, but incorporates updated information on key parameters: 1) Data from IEA World Energy Outlook 2017 Report (WEO, 2017) on current and future oil market conditions; 2) Global oil supply disruption probabilities and spare capacity (Energy Modeling Forum/Beccue et al. 2015, 2018), and 3) Elasticities to capture 
market flexibility and economic sensitivity to price shocks (Uria-Martinez et al. 2018, Oladosu et al. 2018). ${ }^{1}$

\section{BENEFITS TO THE FUNDING DOE OFFICE'S MISSION}

The DOE Strategic Petroleum Reserve Office (SPRO) manages the U.S. Strategic Petroleum Reserve (SPR), which is the world's largest emergency crude oil stock. The recent surge in U.S. oil production has led to changes in global oil market patterns. The U.S. government plans to make partial sales of oil from the SPR over the next 10 years, under existing legislation, and is engaged in ongoing plans to efficiently configure the SPR. The U.S. is a significant member of the IEA, and a participant in IEA stockholding and energy-emergency preparedness planning. This study supports the U.S. DOE SPRO and IEA by providing insights on the value of emergency oil stocks over the next 30 years, serving as an input into discussions about future oil market challenges among IEA member-, and with non-IEA, countries.

\section{TECHNICAL DISCUSSION OF WORK PERFORMED BY ALL PARTIES}

The primary methodology for evaluating the economic benefits of IEA oil stocks in this study is the simulation of oil supply disruptions and stock use with the Oak Ridge National Laboratory's BenEStock model (Leiby et. al., 2016). The model can be used to examine individual disruption scenarios or simulated in a Monte Carlo risk analysis fashion to produce estimates of the expected benefit. The six key inputs for estimating the strategic economic benefits of stockholding are: 1) Reference Market Conditions for 4 world regions (IEA North America, IEA Asia-Pacific, IEA Europe, and Non-IEA Net Importing countries) ; 2) Oil Supply Disruption Likelihoods; 3) Spare Oil Production Capacity; 4) Emergency Oil Stock Capabilities (draw rate capabilities, stock sizes and fill/refill rates); 5) Market Responsiveness (price elasticities of supply and demand); 6) Macroeconomic Sensitivity to Shocks (GDP elasticities).

BenEStock computes the benefits from using emergency stocks in cases of disruptions as well as stock level, stock use, net oil costs, and other relevant variables. Disruption impacts are modeled on a monthly basis, for up to 36 months in length, over the period from 2018 to 2047 (30 years) for this study. A coordinated emergency stock draw action is triggered in the BenEStock model if an "net disruption" is greater than a specified drawdown threshold level. Net disruption is calculated as the size of the supply loss following a disruption, net of offsets such as spare capacity (but excluding emergency stock draw). A drawdown threshold of 2.0 MMBD is used for the central case in this report. After a drawdown, the emergency stocks can be refilled at exogenously specified refill rates. If the remaining oil shortfall is greater than zero, the world oil price increases. Oil price increases are translated into economic costs to society, mostly composed of Gross Domestic Product (GDP) losses and net oil import costs. Net revenues from emergency oil stock sales and refill purchases are also calculated.

\footnotetext{
${ }^{1}$ The essential methodology is maintained to be consistent with the prior 2012 study, and we draw on that report for some of the discussion here.
} 


\subsection{OVERVIEW WORK PERFORMED BY ALL PARTIES}

The work performed by ORNL and IEA under this CRADA are outlined below.

\subsubsection{OAK RIDGE NATIONAL LABORATORY}

- BenEStock Model Changes and Simulations: ORNL incorporated the most recent WEO 2017 data provided by the IEA into the BenEStock model. Reference oil market paths track the New Policies Scenario in WEO 2017. Disruption risk characterizations, including disruption risk probabilities, sizes and duration, are drawn from the 2015 Stanford Energy Modeling Forum disruption risk assessment for use in the BenEStock simulations. ${ }^{2}$ These data are combined with data from other sources, such as the EIA, to be consistent with average conditions (or the range of base, low and high case scenarios) that are projected for the next 30 years. This period is sufficiently long to assure that the analysis is not sensitive to near-term conditions, and to reflect the long operational life of many emergency stock facilities.

- Updated Estimates of Oil Demand and GDP Elasticities: Similar to other ORNL studies of oil stock benefits, economic damages are measured based on estimated GDP losses and increased import costs, or wealth transfers, during shocks. Recent studies at ORNL are used to update the parameters for estimating these costs as follows: 1) Regional short-run elasticities for estimating the price impacts of oil disruptions were based on recent surveys of regional supply-demand responsiveness, including a recent formal meta-analysis by ORNL, accounting for expert recommendations of the IEA or DOE. 2 Oil price-GDP elasticities for estimating the GDP losses from changes in oil prices following a disruption are based on surveys of this oil-macroeconomic relationship, including a formal ORNL meta-analysis of studies of the oil price elasticity of GDP.

- Engaged IEA Member Countries in Finalization of Parameters and Assumptions: ORNL provided the IEA with an initial list of parameters and assumptions used to run the BenEStock model, this list was shared with the delegates from the Standing Group on Emergency Questions (SEQ) for comments. A final set of parameters were agreed after discussions with the SEQ delegates.

- Compiled and Submitted Reports of Benefit Estimates to IEA: Benefits of stocks are determined from avoided damages, in paired comparisons of cases with and without IEA stock use. Outcomes and economic benefits from holding strategic oil stocks were reported as average annual benefits, or annual benefits per barrel of stock held for two regional country-groups comprising most of the world's oil importing regions (IEA-Member countries and non-IEA economies).

- Presented Benefits Results to IEA Member Countries: ORNL attended two meetings of the IEA SEQ to discuss preliminary and final estimates of the benefits of IEA emergency stocks and respond to comments and questions.

\subsubsection{INTERNATIONAL ENERGY AGENCY}

- Provided WEO 2017 and other Data: The IEA provided confidential data from the WEO 2017 database to ORNL for benchmarking future base (undisrupted) oil market conditions, including prices, regional supplies and demands, and GDP levels. IEA also assisted with data on IEA stocks and reviewed other data and parameters.

- Coordinated with Cost Analysis Study: The IEA supported a parallel effort by an IEA sub-contractor to estimate the cost of holding emergency stocks over the next 30 years, and coordinated the ORNL study with the cost study to ensure consistency of assumptions and data.

- Coordinated Interactions with IEA Member Countries: The IEA coordinated conference calls and two meetings to discuss model parameters and results of the study with SEQ delegates.

\footnotetext{
${ }^{2}$ https://emf.stanford.edu/projects/emf-nodefield-project-num-oil-disruption-risks. "An Updated Assessment of Oil Market Disruption Risks," FINAL REPORT February 5, 2016, Phillip Beccue and Hillard Huntington, Stanford Energy Modeling Forum.
} 


\subsection{RESULTS OF THE STUDY}

The full results of this study are presented in two documents (IEA, 2018; Leiby et al., 2019), and an overview is provided below. The BenEStock model was used in this study to simulate the benefits from emergency stocks in response to a wide range of possible disruptions over a 30year period (2018-2047). Monte Carlo type simulations with 10,000 replications are used to estimate expected values and confidence intervals of net benefits and other relevant variables. This simulation generates randomized values for disruption sizes and durations (3 to 18 months), spare capacity availability, and GDP sensitivity and demand flexibility (elasticities) over the 30year horizon.

\subsubsection{EXPECTED CUMULATIVE ECONOMIC BENEFITS OVER 30 YEARS}

Results show that on average, when an oil stock drawdown occurs it yields collective GDP savings to all oil importers of approximately $\$ 550$ billion ( $0.5 \%$ of GDP), and reduces their import costs by a slightly smaller amount, $\$ 450$ billion (equal to another $0.38 \%$ of GDP) over the 30 -year period. ${ }^{3}$ In extreme drawdown events, the savings are larger than this average result. A summary measure of stockholding benefits is the annual benefits per barrel of emergency IEA stocks held. Table 1 shows the average and $90 \%$ interval of benefits of IEA stocks. The average collective total benefit is about $\$ 61$ per barrel per year of ownership, under base assumptions, representing the expected average annual outcome over 30 years and over many possible sequences of market outcomes, discounted to $2016 \$$ at $3 \%$. Because the oil market is so uncertain, this $\$ 61$ barrel per year represents an average payoff from the insurance provided by stocks, so the actual benefits could be smaller, or much larger. The $90 \%$ interval for benefits under base case conditions reflects uncertainty about these oil market outcomes, particularly about which disruptions might occur and when over the 30-year planning horizon. It ranges from $\$ 11.0$ to $\$ 119.5 / \mathrm{bbl} / \mathrm{year}$. Table 1 also provides undiscounted estimates of average annual benefits per barrel for comparison.

Table 1. Average Annual Benefits per Barrel of total IEA stocks (\$/BBL/Yr): Base Case

\begin{tabular}{|l|r|r|r|}
\hline Benefits of Current IEA vs. No Emergency Stocks & Low & Average & High \\
\hline 3\% Discounting (base case) & $\$ 10.96$ & $\$ 61.27$ & $\$ 119.47$ \\
\hline \%\% Discounting (alternative case) & $\$ 16.99$ & $\$ 99.38$ & $\$ 192.77$ \\
\hline *Low to High range encompasses 90\% of the sample distribution. \\
\hline
\end{tabular}

The total benefits derived from IEA emergency stocks are comprised of benefits for IEA countries and benefits for non-IEA net oil importing countries (Figure 1). In this analysis, the benefits enjoyed by non-IEA countries are higher than the benefits to the IEA. ${ }^{4}$ The principal reason for this is that Non-IEA oil consumption and GDP are projected to grow significantly over the 30-year horizon of the simulation, eventually exceeding collective consumption and

\footnotetext{
${ }^{3}$ For context, reference GDP for the world's importing countries is projected to total $\$ 109$ trillion in 2025 (discounted to 2017), and average annual discounted GDP for all importers over 2018-2047 is expected to be $\$ 110$ trillion.

${ }^{4}$ Non-IEA oil stocks are not assumed to be available in the base case. However, sensitivity cases with $50 \%$ and $100 \%$ availability of Non-IEA stocks used in coordination with IEA stocks are presented below. Coordination of emergency stock uses in all cases is based on consumption shares.
} 
GDP of IEA member countries. The high share in oil consumption and GDP is reflected in a high share of the benefits derived from stocks during a supply disruption.

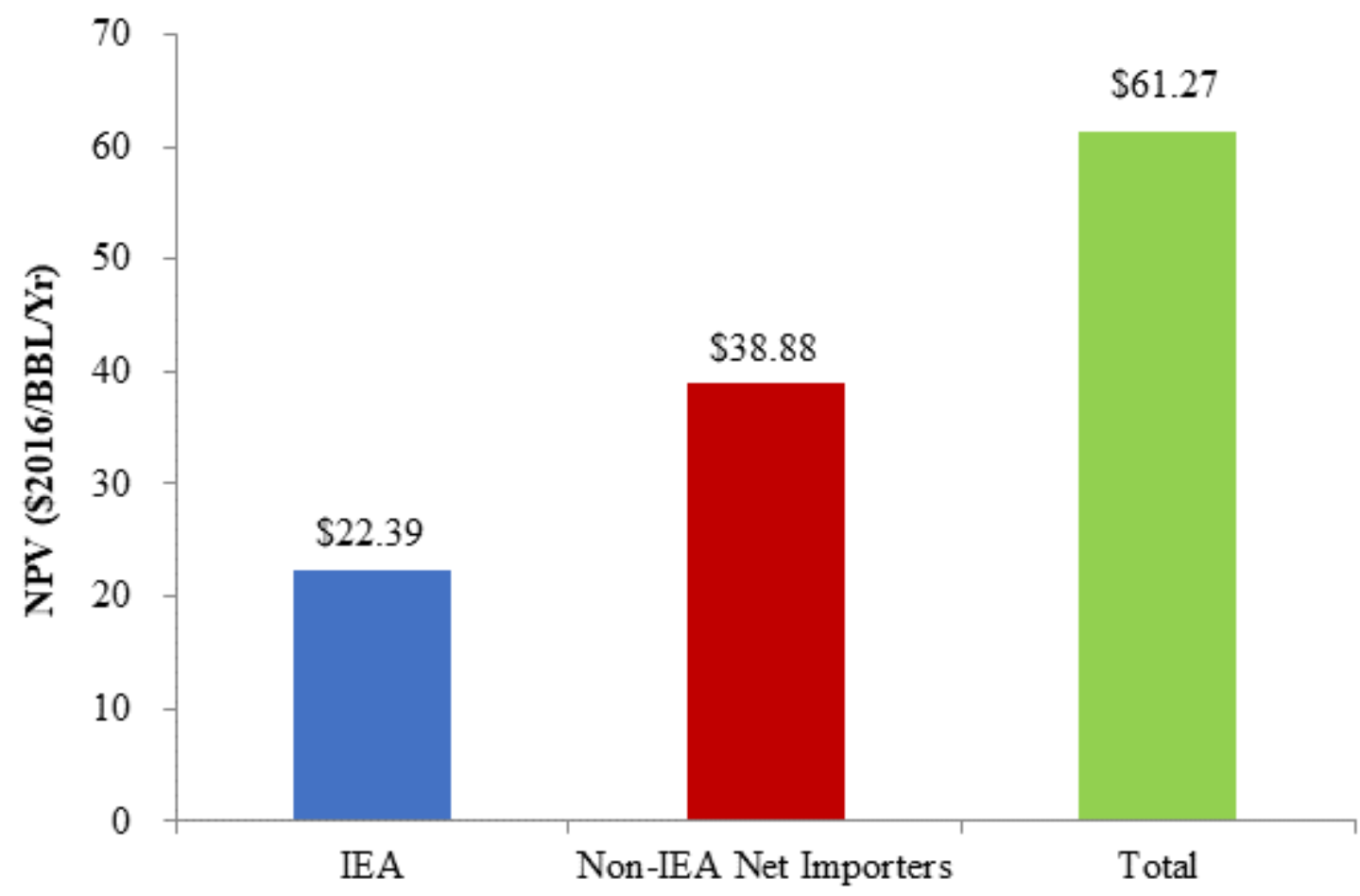

Figure 1. Discounted Average Annual Benefit per BBL/yr of IEA Stocks, by Benefits Region (Base case). Includes Global Benefits to All Oil Importing Countries

\subsubsection{COMPARISON TO 2012 STUDY AND SENSITIVITY ANALYSIS}

The full report compares the new results to those of the 2012 study on stockholding benefits and discusses the (modest) differences. . It also reports the results of a variety of sensitivity cases in which key base assumptions were altered. See the full resports (Leiby et al., 2019; IEA 2018).

\subsubsection{UNQUANTIFIED BENEFITS MAY BE LARGE}

Additional and potentially large benefits can be derived from emergency stockholding. These benefits depend not only on how much stocks are held but also on where stocks are held. They make it more attractive, even for small countries, to maintain emergency stocks. First, stocks can help in coping with domestic shocks (from natural disasters to infrastructure outages) that are not large enough to trigger a coordinated IEA response. Having stocks securely positioned withincountry can better assure that products reach demand locations rather than relying on global stocks and long-range global trade. Second, oil stocks can provide diplomatic benefits for importing countries in the form of increased freedom of action given the threat of, or in the event of, an international supply disruption. Third, strategic stocks provide national security benefits. They can reduce the need for military preparations or intervention for energy security reasons. They also help guarantee the readiness of the national defense sector, which is highly oilintensive, to conduct any other operations related to national security. The relative importance of these different categories will vary across countries. When all these other benefits are taken into 
account, the value of emergency oil stocks goes well beyond the collective protection against the economic costs of a world oil crisis. To the extent that oil stocks reduce the cost of market shocks, natural disasters, or any other interruption in supply, they provide greater independence and reduce costs in non-economic areas as well. Given the scope of this study, none of these additional, difficult-to-quantify benefits are included in the benefits estimates reported here.

\section{SUBJECT INVENTIONS}

No inventions were generated under this study.

\section{COMMERCIALIZATION POSSIBILITIES}

There are no commercialization possibilities from the outputs of this study.

\section{PLANS FOR FUTURE COLLABORATION}

There are currently no plans for further collaboration with the IEA on this topic. However, the IEA is continuing its assessment of future oil market changes and the role of stocks for meeting emerging challenges. Given this, future collaboration or updates on the current study with the IEA are possible.

\section{CONCLUSIONS}

This study provides clarifying insights into the value of IEA emergency stock holdings in the light of recent major changes in the oil market, particularly the significant increase in U.S. oil production. It showed that both IEA member countries and non-IEA oil importing countries benefit from the price moderating effects of IEA emergency oil stocks during disruptions. Base case expected benefits, which are an average of benefits over a range of possible future oil market outcomes, are in the range of $\$ 61 / \mathrm{bbl} / \mathrm{yr}$, and IEA estimated stockholding costs are $\$ 10$ $\$ 12 / \mathrm{bbl} / \mathrm{yr}$. The estimated collective benefits for all oil importers from this updated study are found to be comparable to those from the 2012 study, due to the combination of changes in the oil market, size of available oil stocks, and the global economy. Sensitivity analysis results show that the range of benefits vary with different future outcomes for these determinants and implies an ongoing need for analytical efforts to understand the associated issues and uncertainties. 


\section{REFERENCES}

1. Beccue, Phillip, Huntington, Hillard, 2016. An updated assessment of oil market disruption risks. Energy Modeling Forum Special Report 10, Stanford University, Stanford, California.

2. Beccue, Phillip C., Huntington, Hillard G., Leiby, Paul N. and Vincent, Kenneth R. 2018. An Updated Assessment of Oil Market Disruption Risks. Energy Policy (April).

3. Brown, Stephen P A, and Hillard G Huntington (2010) "Reassessing the Oil Security Premium,” RFF Discussion Paper Series, no. RFF DP 10-05, doi:RFF DP 10-05.

4. IEA (2017) World Energy Outlook, New Policies Scenario

5. Leiby, Paul N. David Bowman, Gbadebo Oladosu, Rocio Uria Martinez, Kenneth Vincent 2012. Benefits of Emergency Oil Stocks A Study of IEA Stocks and Benefits. Final Draft, October 3, 2012. Oak Ridge National Laboratory (ORNL)

6. Oladosu, Gbadebo A., Paul N. Leiby, David C. Bowman, Rocio Uría-Martínez, and Megan M. Johnson. "Impacts of oil price shocks on the United States economy: A meta-analysis of the oil price elasticity of GDP for net oil-importing economies." Energy Policy 115 (2018): 523-544.

7. Uria-Martinez, Rocio, Paul N. Leiby, Gbadebo A. Oladosu, David C. Bowman, Megan M. Johnson (2018). Using Meta-Analysis to Estimate World Oil Demand Elasticity ORNL/TM2018/1070.

8. Leiby, Paul, David Bowman, Gbadebo Oladosu and Rocio Uria-Martinez (2016) BenEStock Model for U.S. Strategic Petroleum Reserve (SPR) Analysis.

9. International Energy Agency - IEA (2018) Costs and benefits of emergency stockholding. IEA Insight Series. https://webstore.iea.org/insights-series-2018-costs-and-benefits-ofemergency-stockholding

10. Leiby, Paul, David Bowman, Gbadebo Oladosu Rocio Uria-Martinez and Megan Johnson (2019) Benefits of Emergency Oil Stocks: An Updated Study of IEA Stocks and Benefits. ORNL/TM-2018/880 